\title{
Reclaiming the Political in Bosnia: A Critique of the Legal-Rational Nightmare of Contemporary Bosnian Statehood
}

\author{
Jasmin Mujanović $^{1}$
}

Through the lens of Sheldon Wolin's conception of "the political," this essay argues that the post-war Bosnian state, constructed through a fusion of nationalist ethnic cleansing, genocide, kleptocracy, and Western "nation-building," is an ideal representation of the depoliticization process inherent to every state-building project. The experience of state-building in Bosnia-Herzegovina illustrates more broadly the inherently violent and coercive nature of the state form. In place of this tendency, Andrej Grubačić's "radical balkanology" is suggested as representing the potential for a "no state solution" or what is termed a "cultural anarchic" turn for Bosnia and the greater Balkans. [Article copies available for a fee from The Transformative Studies Institute. E-mail address: journal@transformativestudies.org Website: http://www.transformativestudies.org (C2013 by The Transformative Studies Institute. All rights reserved.]

KEYWORDS: Bosnia-Herzegovina, Depoliticization, Apartheid, Anarchism.

"Across the asphalt and concrete of our raped land, comes a band of profiteers, carrying away our wealth...Flags have been sown, the children convinced, the knives distributed, our graveyards divided."

Damir Avidić, "Po Asfaltu i Betonu"2

\footnotetext{
${ }^{1}$ Jasmin Mujanović is a PhD student in Political Science at York University in Toronto, Canada, where his research interests have centered on (re)introducing radical political theory to Yugoslav and Balkan studies. He is a regular contributor to Politics, Re-Spun [http://politicsrespun.org/]. Acknowledgments: I would like to express my sincere appreciation to Deric Shannon for his editorial energies, to Rebecca Kumi for her love and patience, and, most of all, to Amra and Refik Mujanović who sacrificed everything, many times over, that I might be something. Address correspondence to: Jasmin Mujanović, e-mail: jmujanov@yorku.ca.

${ }^{2}$ Unless otherwise indicated, all translations from Bosnian/Croatian/Serbian (BCS) have been done by me, and, as such, any errors are correspondingly my own and in no way those of the original author(s).
}

1937-0229 C2013 Transformative Studies Institute 